\title{
3 \\ Gender equity in the tax-transfer system for fiscal sustainability ${ }^{1}$
}

\section{Patricia Apps}

There has been a significant focus in recent years on the persistent gender pay gap in Australia. According to Australian Bureau of Statistics (ABS), data the gender pay gap, calculated as the difference between women's and men's average weekly full-time equivalent earnings and expressed as a percentage of men's earnings, is around 16 to 18 per cent (WGEA 2016; ABS 2016). A range of explanations have been offered. Among those frequently cited are gender differences in labour supply and career choices driven by a work environment that is insensitive to the needs of women with dependant children. The under-representation of women in leadership roles due to workplace practices is also a major concern. Less attention has been given to the contribution the Australian tax system makes towards widening the pre-tax gender pay gap by widening the netof-tax gender wage gap, creating negative effects on the labour supply and therefore employment earnings of the vast majority of low- and averagewage women.

One of the most extraordinary aspects of the ongoing and longstanding tax reform debate in Australia is the almost complete absence of any reference to the impact on women. Instead, the focus of much of the discussion

1 The research was supported under the Australian Research Council's Discovery Project funding scheme (Project ID: DP120104115). 
has been on lowering tax rates for top income earners, mostly men whose labour supply is known to be less responsive to tax rate changes. Many women, together with low- and average-wage earners generally, now face higher marginal and average tax rates under an income tax system that has become much less progressive. Many partnered mothers as second earners face effective marginal tax rates that are well above the top personal income tax (PIT) rate due to the withdrawal of family payments for dependant children on the basis of joint income. In this chapter, it is argued that the tax system now in place after three decades of incremental reforms is a major determinant of the persistent gender pay gap and that the reforms are ultimately unsustainable due to their negative impact on female labour supply, productivity and the tax base.

Part 2 begins with an outline of the changes to the PIT rate scale and low income tax offset (LITO) and the resulting shift in the tax burden towards those in the middle of the distribution of income. The LITO is characterised here as a tax policy instrument that serves the sole purpose of reducing the transparency of the distributional impact of the reforms in an economy with rising inequality. Treasury's view of bracket creep, the tendency for more wage earners to be drawn into the higher tax brackets purely as a result of inflation, is discussed as an illustration of the underlying long-term agenda of shifting the tax burden from the top towards the middle of the earnings distribution (see Treasury 2015a, 2015b).

In part 3, we turn to the taxation of the family. The analysis first identifies the gradual replacement of universal family allowances by joint income tested payments as a non-transparent strategy for raising tax rates on working partnered mothers. This was done during a period in which the government was simultaneously cutting taxes on top incomes. The section goes on to present data indicating a strong negative effect of this on female labour supply and household saving.

Finally, part 4 discusses the challenges presented by demographic change arising from the fall in the total fertility rate (TFR) from around 3.5 in the early 1960 s to 1.8 today, and argues that the current tax, child care and retirement incomes policy settings are unsustainable. The analysis illustrates the misleading views on tax reform generated by the prevailing Treasury approach of modelling the economy as if we lived in a world 
in which women did not exist (see, for example, the computable general equilibrium (CGE) modelling in the Treasury Working Paper by Cao et al. (2015) and in KPMG (2010)).

\section{Taxation of individual incomes}

\section{Income tax reform}

The progressive rate scale of the PIT applies to individual incomes and therefore has the advantage that women on lower pay face lower marginal tax rates (MTRs) and, in turn, lower average tax rates (ATRs) than men on higher pay. The progressivity of the system reduces simultaneously the net-of-tax gender pay gap and the overall degree of inequality. In addition, a progressive individual-based system reduces distortions in the incentive to work outside the home, by applying lower taxes on women with lower earnings, who are known to be more responsive to changes in the net wage than higher-earning men. As discussed in Chapter 9 (Stewart, Voitchovsky and Wilkins), women make up only 23 per cent of top decile taxpayers and 17 per cent of those in the top 1 per cent of the income distribution.

These advantages of a progressive, individual income tax are well recognised. Yet recent decades have seen the transformation of the Australian income tax towards a far less progressive system, and one with an effective rate scale that is no longer strictly progressive. In 1985-86, the top rate was 60 cents in the dollar. By 1990-91, it had fallen to 47 cents, funded largely by accumulated revenue from bracket creep. The further accumulation of revenue from bracket creep over the next decade subsequently funded major changes that gave the greatest gains to those in the upper percentiles of income. From 2004-05 to 2008-09, the top bracket limit, the income level at which the top tax rate cuts in, rose from $\$ 70,000$ to $\$ 180,000$, providing large gains for those on high incomes. In 2007-08, the top marginal rate fell a further two percentage points, providing further gains for high-income earners. At the same time, individuals on very low incomes benefited from a rising zero rated threshold with the gradual expansion of the LITO from \$243 in 2004-05 to \$1,500 in 2010-11 and 2011-12. The withdrawal of the LITO at a fixed rate effectively raised MTRs across a new low income tax bracket to deny income earners above the upper threshold of the bracket the relatively small lump sum gains 
from a rising zero-rated threshold. The key role of the LITO was to make the higher effective MTRs across this bracket of low incomes, and the consequent loss of strict progressivity in the rate scale, non-transparent.

Table 3.1 illustrates the change in the MTRs when the LITO is combined with the PIT rate scale in the 2015-16 financial year. The Temporary Budget Repair Levy is excluded. Panel A of the table lists taxable income brackets and MTRs that apply to each under the PIT scale. Panel B reports the true rate scale when the LITO of $\$ 445$ is included. The LITO increases the zero-rated threshold from $\$ 18,200$ to $\$ 20,542$ and its withdrawal at 1.5 cents in the dollar from $\$ 37,000$ raises MTRs by this amount until it is fully withdrawn at the upper threshold of $\$ 66,666$. The effect is to deny taxpayers above this threshold the lump sum gain of $\$ 445$ from the higher zero-rated threshold.

Table 3.1: PIT + LITO marginal tax rate scales, 2015-16

\begin{tabular}{|l|c|l|c|}
\hline \multicolumn{2}{|c|}{ Panel A: PIT } & \multicolumn{2}{c|}{ Panel B: PIT + LITO (\$445) } \\
\hline Taxable income bracket & MTR & Taxable income bracket & MTR \\
\hline$\$ 0-\$ 18,200$ & 0.00 & $\$ 0-\$ 20,542$ & 0.00 \\
\hline$\$ 18,201-\$ 37,000$ & 0.19 & $\$ 20,543-\$ 37,000$ & 0.19 \\
\hline$\$ 37,001-\$ 80,000$ & 0.325 & $\$ 37,001-\$ 66,666$ & 0.34 \\
\hline$\$ 80,001-\$ 180,000$ & 0.37 & $\$ 66,667-\$ 80,000$ & 0.325 \\
\hline$\$ 180,001+$ & 0.45 & $\$ 80,001-\$ 180,000$ & 0.37 \\
\hline- & - & $\$ 180,001+$ & 0.45 \\
\hline
\end{tabular}

Source: Author's calculations.

A LITO of $\$ 445$ is all that is required in the 2015-16 financial year to conceal the fact that the true rate scale is not strictly progressive. As noted above, in the 2010-11 and 2011-12 financial years the LITO was $\$ 1,500$. In those years, the zero-rate threshold was not the $\$ 6,000$ reported under the PIT scale, but $\$ 16,000$. It is clear that the changes in the LITO since 2004-05 have been carefully crafted to conceal the rise in effective MTRs on incomes below average annual full-time earnings when, at the same time, the government was reducing tax burdens at much higher income levels by lowering top rates and raising the thresholds at which they applied. The changes can be shown to have resulted in a significant shift in the tax burden from the 'top' to the 'middle' during a period of increasing inequality. 


\section{Rising inequality}

There is now an extensive literature on the rise in inequality of income and wealth in developed economies (see, for example, Atkinson 2015; Piketty et al. 2014; and Piketty and Saez 2003). Apps and Rees (2013) present an analysis of changes in the distribution of income in Australia drawing on data for matching samples of couples selected from the two most recent ABS Household Expenditure Surveys (HES), HES 2003-04 and HES 2009-10. The samples are selected on the criteria that both partners are aged from 20 to 60 years and the primary income partner is employed for at least 25 hours per week. The HES 2003-04 sample contains 2,447 couple income unit records and the HES 2009-10 sample, 2,408 records. The results are summarised below.

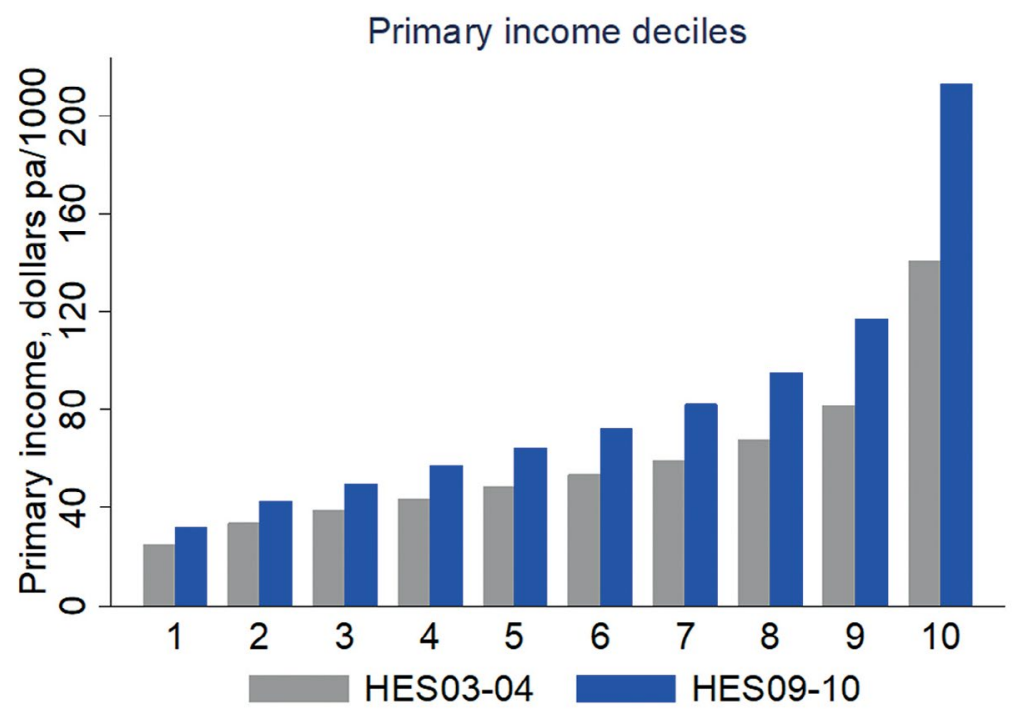

Figure 3.1: Rising inequality

Source: Author's calculations based on ABS HES data for 2003-04 and 2009-10.

The study finds a significant increase in inequality based on the change in the distribution of nominal primary private incomes over the six-year period. Figure 3.1 shows graphically the decile distribution of nominal primary private incomes in each of the two survey years. ${ }^{2}$ In decile 1 , there is a 28.6 per cent increase. This is followed by small increments up

2 Figure 3.1 expands the quintile distributions in Table 2 of Apps and Rees (2013) into decile distributions. 
to decile 5, in which the rise is 32.7 per cent. The percentage gains are slightly larger in the next three deciles. Thereafter, the gains rise more steeply and quite dramatically towards the top decile. In decile 9, the nominal increase is 43.27 per cent and in decile 10 it is 52.17 per cent. The nominal rise in the top percentile is 71.02 per cent.

Figure 3.2 plots the decile distribution of nominal tax cuts over the period. The profile reflects the concentration of billions of dollars of tax cuts in the top percentiles and the shift in the tax burden towards the 'middle'. The lowest gain appears in decile 6 , at less than $\$ 600$. In decile 10 the gain is around $\$ 9,000$ (40 per cent of total) and in the top percentile, close to $\$ 50,000 .^{3}$

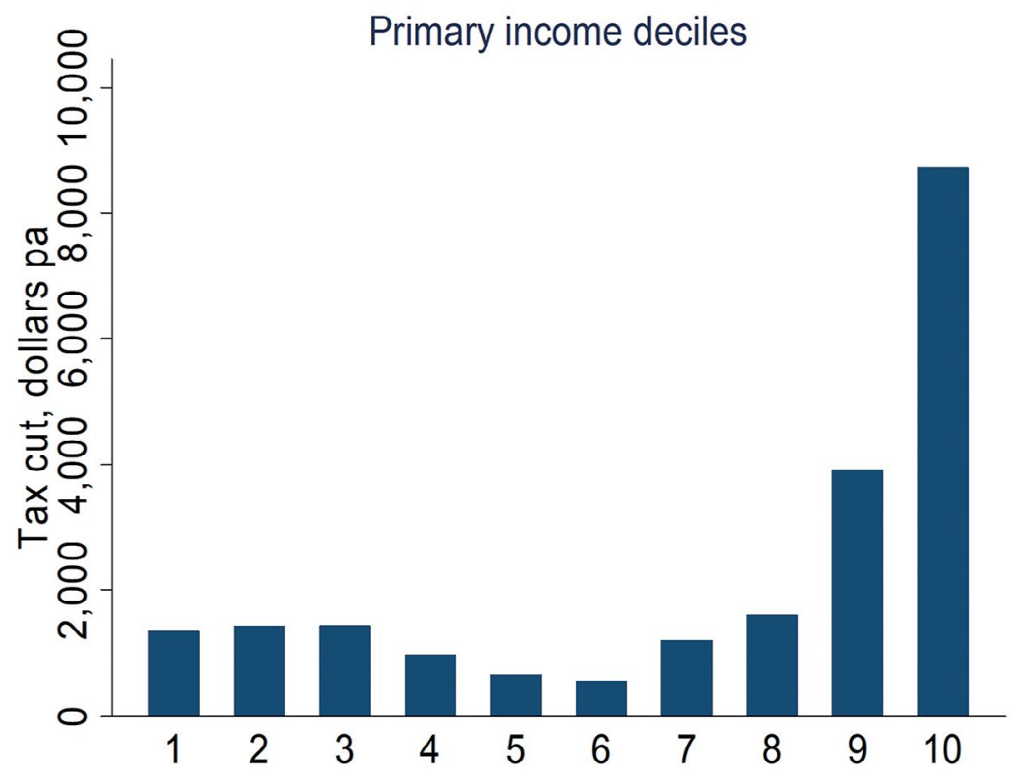

Figure 3.2: Shift in tax burden towards the 'middle'

Source: Author's calculations based on ABS HES data for 2003-04 and 2009-10.

The recent Treasury reports, Re:Think (Treasury 2015b) and the Intergenerational Report (Treasury 2015a), argue for lower income taxes to protect low- and middle-income earners from the adverse effects of bracket creep. Both documents claim to show that 'bracket creep affects lower and middle income earners proportionally more than higher income

3 This direction of personal income tax (PIT) reform with rising inequality it not unique to Australia. For an across-country survey see Peter et al. (2010). 
earners' by comparing ATRs on three incomes in 2013-14 with the rates that will apply in 2023-24 if the incomes rise to expected levels and the PIT rate scale, LITO and Medicare Levy remain unchanged. The three incomes are $\$ 37,500, \$ 75,000$ and $\$ 150,000$. The income of $\$ 75,000$ is selected as representative of average annual ordinary full-time earnings in 2013-14, and so the lower and upper income figures represent half and twice average annual ordinary full-time earnings.

By 2023-24, the three incomes are projected to rise to $\$ 52,000, \$ 104,000$ and $\$ 208,000$, respectively, as shown in Table 3.2a. The ATR is calculated to rise by $7.5,4.7$ and 3.8 percentage points from the lowest to the highest income. While the decline in the increments in the ATR as income rises does in fact demonstrate that lower- and middle-income earners are disadvantaged proportionally more than higher-income earners, in terms of absolute burdens (not reported in either document) the reverse is the case. As shown in the last row of Table 3.2a, the additional tax burden on the income of $\$ 208,000$ is $\$ 7,904$, which is over twice that of $\$ 3,900$ on the income of $\$ 52,000$ and over 60 per cent higher than the additional tax on the middle income. Thus, in absolute terms, high-income earners are the main beneficiaries of measures to reduce bracket creep.

Table 3.2a: Change in ATRs and tax burdens from 2013-14 to 2023-24

\begin{tabular}{|l|c|c|c|}
\hline Income in 2013-14 & $\$ 37,500$ & $\$ 75,000$ & $\$ 150,000$ \\
\hline Income in 2023-24 & $\$ 52,000$ & $\$ 104,000$ & $\$ 208,000$ \\
\hline ATR in 2013-14 & 10.3 & 22.7 & 30.5 \\
\hline ATR in 2023-24 & 17.8 & 27.4 & 34.3 \\
\hline ATR increment & 7.5 & 4.7 & 3.8 \\
\hline Tax increment & $\$ 3,900$ & $\$ 4,888$ & $\$ 7,904$ \\
\hline
\end{tabular}

Source: Author's calculations.

Table 3.2b: Change in ATRs and tax burdens from 2003-04 to 2013-14

\begin{tabular}{|l|c|c|c|}
\hline Income in 2003-04 & $\$ 24,500$ & $\$ 49,000$ & $\$ 98,000$ \\
\hline ATR in 2003-04 & 15.4 & 23.7 & 35.1 \\
\hline ATR increment & -5.1 & -1.0 & -4.6 \\
\hline Tax increment & $-\$ 1,913$ & $-\$ 750$ & $-\$ 6,900$ \\
\hline
\end{tabular}

Source: Author's calculations. 
In the light of Treasury's new concern for the 'middle', it is of interest to compare the results with changes in the previous decade. Table $3.2 \mathrm{~b}$ repeats the calculation for 2003-04 to 2013-14. In 2003-04, average annual full-time earnings were around $\$ 49,000$, and so the matching incomes are $\$ 24,500, \$ 49,000$ and $\$ 98,000$. ATR increments over the decade are negative, with the lowest proportional gain for the middle income. In terms of absolute burdens, the gain for the middle income is $\$ 750$, a small fraction of the $\$ 6,900$ tax cut for the top income, which is in turn three times the gain for the lowest income. The ATR and tax increment profiles reflect a decade of rate changes that shifted the tax burden from top incomes toward the middle, as indicated in Figure 3.2. If we combine the two decades and repeat the calculation, we find that positive gains are limited to the top income.

Given this reform record, the rate scale changes enacted since the 2016-17 Budget can be viewed as consistent with a long-term policy agenda of lowering taxes across the top percentiles of income. Raising the current upper bracket limit of $\$ 80,000$ to $\$ 87,000$ for the 32.5 cent rate of the PIT provides a lump sum of $\$ 315$ for individual taxpayers above $\$ 87,000$ but no gain for taxpayers below the $\$ 80,000$ threshold. Removing the Temporary Budget Repair Levy of 2 cents in the dollar will provide a rising absolute gain for those above $\$ 180,000$, the threshold for the levy. Very few employed women gain from these rate changes, and less than half of employed men have incomes of over $\$ 80,000$. As in preceding years, the rate scale changes will add to the budget deficit.

\section{Labour supply incentives}

It is frequently claimed that lower tax rates on top incomes under a less progressive rate scale will achieve efficiency gains from reduced labour supply disincentive effects. However, it is difficult to support this view because neither cross-section nor panel data show a sufficiently large increase in top earners' labour supply with rising top wage rates. ${ }^{4}$ Some studies circumvent this evidence by directing attention towards the effects of tax policy on earnings, rather than labour supply. However, as Piketty et al. (2014) argue, a fall in earnings or taxable income in response to a higher tax rate is largely a reflection of an increase in tax avoidance and evasion as

4 See, for example, the profiles of earnings and hours of work based on the ABS HES data samples of couples in Apps and Rees (2013, Table 2.6). Studies for other countries report similar findings. See, for example, Moffitt and Wilhelm (2000). 
income is under-reported or diverted to forms that are subject to lower tax rates, or to weakened bargaining power and consequently a lower share of profits, for example of senior executives in diverting the flow of profits from company shareholders to themselves. The authors recommend that tax avoidance and evasion, which essentially are a symptom of inadequate tax system design, should be dealt with directly and not through the tax rate scale. Based on low estimates of labour supply elasticities at the top, they propose a higher top tax rate in response to rising wage and income inequality.

This recommendation is consistent with the results for the structure of optimal tax rates reported in Andrienko et al. (2016) (see also Apps et al. 2014). Drawing on survey data for Australia, the UK and the US, the study constructs percentile distributions of primary wage rates and computes the profiles of labour supply elasticities across each wage distribution. Labour supply elasticities are found to be relatively high across the lower wage percentiles, to flatten across the middle and to approach zero towards the top. As a consequence, the optimal structure of MTRs is found to become more progressive as inequality rises in each of the three countries. Shifting towards a less progressive PIT rate scale to achieve a given degree of redistribution can therefore be expected to come at the cost of a worsening of work incentives where they really matter as well as in a reduction in fairness of the distribution of tax burdens.

The Andrienko et al. (2016) analysis highlights the importance of analysing the efficiency effects of a tax on individual earnings by drawing on a modelling approach that does not restrict the labour supply elasticity to a constant across the wage distribution and also does not represent the PIT by a simple flat-rate tax, as in the Treasury Working Paper by Cao et al. (2015) and in KPMG (2010, 2011). Based on a CGE model in which the total population of households is represented as a single person, Cao et al. assert that in general 'progressivity raises the marginal excess burden of a tax, which implies the marginal excess burden of the modelled personal income tax will understate the welfare cost of raising revenue via the actual personal income tax' (2015, p. 23). The authors appear not to recognise that when labour supply elasticities fall sharply with the wage and approach zero towards the top percentiles, as reported in Andrienko et al., an income tax with a progressive rate scale can be expected to dominate a flat-rate tax with respect to both efficiency (work incentives) and fairness. 
In addition to, and largely because of, these limitations of their analysis, Cao et al. and KPMG claim to find that a consumption tax is less distortionary than an earnings tax. However, such an assessment is outside the scope of their model, based as it is on a single-person household. Most adults of working age live in couple households. When the tax system is based on earnings, these can be observed and taxed separately at marginal rates that minimise the disincentive effects on labour supply. On the other hand, individual consumptions within the household cannot be observed and therefore cannot be taxed on an individual basis. Consumption taxation is necessarily joint taxation. As a more limited policy instrument, a consumption tax cannot be superior to a well-designed earnings tax.

\section{Taxation of family incomes}

\section{Family tax reform}

The tax design problem for the two-parent family is more complicated than that for the single individual because of the need to consider the choice of tax unit in addition to the rate scale: should couples be taxed on the basis of their individual incomes or on their joint income? The two systems have very different outcomes for the distribution of the tax burden by gender, the net-of-tax gender pay gap and the overall distribution of the tax burden across households.

In choosing the optimal tax unit, we need first to recognise that the economics of the two-parent family differs fundamentally from that of the single-person household. The presence of a dependant child, and especially a preschool-aged child, creates an additional work choice. One partner can work at home providing child care and other domestic services as an alternative to working in the market and buying in care and related goods and services. In effect, the family is a small economy engaged to varying degrees in untaxed household production and exchange, where the latter creates an implicit wage within the household. ${ }^{5}$ Consequently, we can expect the labour supply decision of the partner with the option of working at home to be more responsive to both average and marginal

5 It is a mistake to label home child care and domestic work in the two-parent family as 'unpaid', just because the exchange process within the household may be implicit. For a model of the household as a small economy with intra-household production and exchange/trade, see Apps (1982). There may also be lump sum transfers as in any small or large economy in which there is centralised decisionmaking and a concern for equity (see Apps and Rees 1988). 
tax rates. Moreover, the hourly cost of child care has to be regarded as an additional tax on her wage, rather than on that of her partner, who would be going out to work in any case.

An important property of a system of family taxation based on the individual as the tax unit is that the marginal rates faced by each partner are independent. As noted in the preceding section, under a progressive rate scale a lower MTR typically applies to the income of the partner with the lower earnings and the labour supply that is more sensitive to the tax rate. In contrast, under joint taxation the MTRs faced by partners are interdependent; for example, if the male partner as primary earner is fully employed, the question of whether the female partner will take a job depends on the change in the household's total tax bill that results, including any effect on the male partner's MTR of her increase in income, that is, it depends on the incremental tax burden with respect to her work decision. The effective or true tax rate she faces can be well above that of her partner's rate.

The high efficiency cost of joint taxation due to the higher effective MTRs on the second earner has long been recognised in the literature (Boskin and Sheshinski 1983; for an overview see Apps and Rees 2009). Nevertheless, over recent decades Australia has shifted from the individual as the tax unit for the family to a system of 'quasi-joint' taxation by switching from universal to joint income-tested family payments. In the early 1980s, families received universal child payments and paid tax on the basis of individual incomes under the PIT scale. The first step towards joint income-tested child payments was the introduction of the 'Family Income Supplement' during the Hawke and Keating years in the late 1980s. Family cash benefits under this reform were initially paid together with universal family allowances, which had not been indexed for a number of years. In 2000, the Howard Government combined the two payments in family tax benefit part A (FTB-A), and in subsequent Budgets completely eliminated universality. This has had the effect of raising MTRs on the second income to well above the top rate of the PIT scale.

An argument frequently used in the Australian literature in support of this direction of reform appears in the Henry Review (Henry et al. 2009). The Review states: 
The personal income tax structure should be the sole means of delivering progressivity in the tax system, supporting the more direct re-distributional role of the transfer system (Part 1, Overview, p. 29).

It goes on to argue for payments tested on family income: ${ }^{6}$

because family payments in Australia are paid at relatively high rates to achieve adequate levels of support for low-income families, it would be extremely costly to provide universal payments. Phasing out payments using a low withdrawal rate can provide some level of assistance to most families without the full cost of a universal payment (Part 2, pp. 556-557).

The argument fails to recognise that it is the disincentive effects of the structure of MTRs on labour supplies, and not simply the size of the transfer, that determine the real economic cost of a tax-transfer system. ${ }^{7}$ Given the evidence on the second earner/female labour supply elasticities, a tax system that imposes effective rates on the incomes of second earners that are well above the top rate of the PIT scale applying to primaryearner incomes cannot be less costly, in terms of the real economic cost, than a well-designed, strictly progressive rate scale.

In the international literature, support for joint taxation draws on the view that horizontal equity, defined in the Mirrlees Review as taxing 'all families with the same joint income equally', requires joint taxation (Institute for Fiscal Studies and Mirrlees 2011). An implication of this 'principle' is that couples with the same total income are equally well off regardless of how much is earned by each partner-a high-wage singleearner household is no better off than one containing two low-wage earners working twice the hours for the same total income. The view implies that home production (e.g. parental child care) does not contribute to family welfare. While widely rejected, many (mostly male) economists continue to think of non-market time exclusively as the pure consumption of 'leisure' rather than production. The Mirrlees Review recommends retaining the individual as the tax unit for the formal income tax system but basing the withdrawal of family payments on joint income-in other words, implementing a quasi-joint family tax system as in Australia.

6 For a detailed analysis of the family tax recommendations of the Henry Review, see Apps (2010).

7 Similarly, the rhetoric of 'middle-class welfare' reflects a misunderstanding of 'cost' in economics. 
In addition to home production, the horizontal equity principle ignores the tax design implications of a high degree of primary income inequality. Based on a model that takes account of the wage rates of second earners and variation in child care prices as determinants of across household heterogeneity in second-earner labour supply, Apps and Rees (2017) find that individual taxation strongly dominates a system of joint taxation, or of income splitting as in the US, on equity grounds. An important driver of the result is the sharp rise in wage rates in the top percentiles of the primary wage distribution. A system of full income splitting provides topwage primary earners the opportunity for tax avoidance simply by having the second earner substitute untaxed household production for market work. Switching to individual taxation, by removing this opportunity, leads to a much fairer distribution of the tax burden at a lower efficiency cost - there are gains in both equity and efficiency.

A partial or quasi-joint family tax system can closely approximate the outcome of full income splitting when the additional revenue collected from the higher MTRs on second incomes contributes to the funding of tax cuts for the top percentiles of income. We now turn to numerical examples to illustrate the structure of marginal and ATRs under the Australian quasi-joint family tax system.

\section{Marginal and average tax rates, 2015-16}

The change in the structure of MTRs with the withdrawal of family payments on joint income is illustrated in Tables 3.3 and 3.4 for a family with two dependant children in the 2015-16 financial year. Table 3.3 reports the profile of MTRs and ATRs that apply under the PIT scale, LITO and FTB-A if the family is single income. Table 3.4 goes on to show the rates that apply to the second income in a family in which the primary income is $\$ 60,000$. While the tax system also includes the Medicare Levy with exemptions and reductions based on joint income, and family tax benefit part B (FTB-B) withdrawn on the second income, these elements are omitted in order to focus on the impact of joint income-testing payments made in respect of each dependant child under FTB-A. The example assumes one child is under 13 years and the second is aged from $13-18$ years.

The total 2015-16 Maximum Rate of FTB-A is $\$ 12,238$, the sum of the Maximum Rate of $\$ 5,412.95$ for a dependant child under 13 years and the Maximum Rate of $\$ 6,825.50$ for a child aged $13-18$ years. The 
total Maximum Rate is withdrawn at 20 cents in the dollar on a family income above $\$ 51,027$ up to the Base Rate. The Base Rate is $\$ 2,230.15$ per child, and is withdrawn at 30 cents in the dollar on a family income above $\$ 94,316$.

Table 3.3: Tax rates 2015-16: Single income two-child family

\begin{tabular}{|l|c|c|c|}
\hline Taxable income bracket & MTR & TAX $^{*} \$$ & ATR $^{*}$ \\
\hline$\$ 0-\$ 20,542$ & 0.00 & $-12,238$ & -0.60 \\
\hline$\$ 20,543-\$ 37,000$ & 0.19 & $-9,111$ & -0.25 \\
\hline$\$ 37,001-\$ 51,027$ & 0.34 & $-4,342$ & -0.09 \\
\hline$\$ 51,028-\$ 66,666$ & 0.54 & 4,103 & 0.06 \\
\hline$\$ 66,667-\$ 80,000$ & 0.525 & 11,103 & 0.14 \\
\hline$\$ 80,001-\$ 89,918$ & 0.57 & 16,757 & 0.19 \\
\hline$\$ 89,919-\$ 94,316$ & 0.37 & 18,383 & 0.19 \\
\hline$\$ 94,317-\$ 109,183$ & 0.67 & 28,344 & 0.26 \\
\hline$\$ 109,184-\$ 180,000$ & 0.37 & 54,547 & 0.30 \\
\hline$\$ 180,001+$ & 0.45 & - & - \\
\hline
\end{tabular}

* At upper-income threshold.

Source: Author's calculations.

Up to the threshold income of $\$ 51,027$ for the Maximum Rate of FTB-A, MTRs are set by the PIT scale and LITO (see Table 3.1). Thereafter, with the withdrawal of the Maximum Rate at 20 cents in the dollar above this threshold the MTR rises to 54 cents in the dollar. At $\$ 66,666$, the LITO is fully withdrawn and so the MTR falls to 52.5 cents in the dollar. At the threshold income for the Base Rate of FTB-A, the MTR rises to 67 cents in the dollar, the sum of the 37 cents PIT rate and 30 cents withdrawal rate of the Base Rate.

The key point to note is that the true MTR across each bracket in the second column of the table is the sum of the PIT rate and the withdrawal rates of the LITO and FTB-A. The third column reports the family's tax at the upper-income threshold calculated as the sum of tax payable under the MTR scale in the second column, net of $\$ 12,238$ as a universal payment. Income testing the FTB-A payment does not remove its universality, it simply changes MTRs and lump sums - that is, the marginal rate structure of the tax system that funds the universal payment. The lump sum for each taxpayer is calculated as the difference between: 
a. the amount of tax that would be payable if the MTR on the last dollar earned applied to the taxpayer's total income

b. the amount that is actually paid under the true rate scale plus FTB-A as a universal payment.

The importance of recognising that effectively every individual faces two tax parameters, a lump sum and a MTR, lies in the following: the lump sum has effects on total income only and so does not distort work decisions at the margin. It therefore has no efficiency cost. The MTR, on the other hand, gives rise to an efficiency loss due to the disincentive effect arising from the distortion it creates in the relative price of time spent in home vs market production. Thus, the true economic cost of the tax system depends only on the latter efficiency loss.

While leaving the universality of FTB-A in place, targeting on joint income has, in addition to a high efficiency cost, serious distributional consequences, as illustrated in Table 3.4. The table lists the true MTR scale and ATRs faced by the second partner contemplating going out to work in a household with a primary income of $\$ 60,000$. She is denied a tax-free threshold, and instead pays 20 cents in the dollar up to the limit of the true zero-rated threshold of $\$ 20,542$. She then pays 39 cents instead of 19 cents across the next bracket. At $\$ 34,317$, her marginal rate goes to 49 cents in the dollar due to the withdrawal of the Base Rate of FTB-A at 30 cents in the dollar. At the $\$ 37,000$ bracket point her MTR goes to 64 cents.

Table 3.4: Primary income $=\$ 60,000$ pa: Tax rates on second income

\begin{tabular}{|l|c|c|}
\hline Taxable income, $\$$ pa & MTR & ATR $^{*}$ \\
\hline$\$ 0-\$ 20,542$ & 0.20 & 0.20 \\
\hline$\$ 20,543-\$ 29,918$ & 0.39 & 0.26 \\
\hline$\$ 29,919-\$ 34,316$ & 0.19 & 0.25 \\
\hline$\$ 34,317-\$ 37,000$ & 0.49 & 0.27 \\
\hline$\$ 37,001-\$ 49,183$ & 0.64 & 0.36 \\
\hline$\$ 49,184-\$ 60,000$ & 0.34 & 0.36 \\
\hline
\end{tabular}

* ATR at upper-income threshold.

Source: Author's calculations.

The ATR profile in the third column of the table gives an indication of the extent to which withdrawing family payments on joint income, by shifting the tax burden towards two-earner households, shifts the burden 
towards partnered mothers as second earners. At $\$ 50,000$, the effective tax on the second income is $\$ 17,991$, which gives an ATR of 36 per cent, as shown in the table. If we include the Medicare Levy and the 2015-16 FTB-B payment of $\$ 3,139$ for a family with two dependant children aged five to 18 years, ${ }^{8}$ the tax on the second income rises to $\$ 22,130$ and her ATR to 42.26 per cent. ${ }^{9}$

Even under an individual-based income tax, with both partners facing the same rate scale and receiving the same non-means-tested family payment, a two-earner family is disadvantaged relative to a single-earner family at any given primary income and wage pair because the former contributes more to the tax revenue that funds the family payment. For example, the contribution to tax revenue by a single-income family with a primary income of $\$ 60,000$ under the PIT scale, LITO and Medicare Levy is $\$ 12,147$. If the second partner switches from untaxed work at home to working in the market for an income of $\$ 50,000$, she contributes an additional $\$ 8,547$, which raises the two-earner family's total contribution to $\$ 20,694$.

To gain an insight into the potential losses in terms of both fairness and tax revenues under the current family tax and child care subsidy system, we draw on data for a sample of 'in-work' two-parent families selected from the ABS Survey of Income and Housing (SIH) 2013-14 on the criteria that the primary income partner is employed for at least 25 hours per week and earns at least $\$ 10,000$ per annum, both partners are aged from 20 to 60 years and a dependant child is present. The sample contains 2,436 records. The data on second hours indicate a very high degree of heterogeneity, with around a third of the sample (798 records) containing a second earner in full-time work, more than a third (931 records) with a second earner in part-time work, and the remainder (707) with only one partner in work. Relatively little of this heterogeneity can be explained by demographics or by the second wage. The average number of dependant children is 1.77 for the full-time group, 1.94 for the part-time group, and 1.95 for the non-participation group, while predicted gross wage rates tend to be marginally higher for the part-time group than for nonparticipants or for those employed full time.

8 Note that when FTB-B is included, the universal transfer for a primary earner on $\$ 60,000$ rises by the FTB-B rate.

9 The withdrawal of FTB-B at 20 cents in the dollar raises the MTR on the second income by that amount from $\$ 5,402$ to $\$ 21,097$. 
To indicate the potential revenue losses from labour supply disincentive effects, we compare taxes on the second income for low and high second hours at a given primary income. We first rank all households by quintiles of primary income and then split each quintile into two subsamples defined with respect to median second hours of work. Households with second hours below the median are labelled ' $\mathrm{H1}$ ' and those with second hours at or above the median ' $\mathrm{H} 2$ '. ${ }^{10}$ Table 3.5 a reports the data means of second annual hours and earnings and the annual income tax on the second income, labelled ' 2 nd tax', for each household group across the distribution of primary income. The gap between the $\mathrm{H} 1$ and $\mathrm{H} 2$ '2nd tax' data means indicates the very significant losses to tax revenue associated with persistent zero or low second hours.

Table 3.5a: Second-earner income, taxes and hours by primary income (SIH 2013-14)

\begin{tabular}{|l|l|c|c|c|c|c|}
\hline \multicolumn{2}{|l|}{ Primary income quintiles \$pa } & 38,601 & 61,726 & 81,663 & 109,065 & 222,523 \\
\hline \multirow{3}{*}{ H1: } & 2nd hours pa & 57 & 329 & 473 & 449 & 307 \\
\cline { 2 - 7 } & 2nd income \$pa & 3,297 & 6,867 & 16,357 & 17,499 & 21,902 \\
\cline { 2 - 7 } & 2nd tax \$pa & 114 & 699 & 1,360 & 1642 & 3,544 \\
\hline \multirow{2}{*}{ H2: } & 2nd hours pa & 1,619 & 1,936 & 2,009 & 1,971 & 1,980 \\
\cline { 2 - 7 } & 2nd income \$pa & 26,527 & 40,891 & 52,208 & 62,141 & 80,170 \\
\cline { 2 - 7 } & 2nd tax \$pa & 2,101 & 5,283 & 8,579 & 11,487 & 17,654 \\
\hline
\end{tabular}

Source: Author's calculations based on ABS HES data for 2013-14.

Table 3.5b: FTB-A payments by primary income: Two children aged 5 to 18 years

\begin{tabular}{|l|l|c|c|c|c|c|}
\hline \multicolumn{2}{|l|}{ Primary income quintiles \$pa } & 38,601 & 61,726 & 81,663 & 109,065 & 222,523 \\
\hline H1: & FTB-A & 10,358 & 5,618 & 2,689 & 1,308 & 136 \\
\hline H2: & FTB-A & 4,505 & 1,836 & 385 & 24 & 30 \\
\hline
\end{tabular}

Source: Author's calculations based on ABS HES data for 2013-14.

Table 3.5b shows the impact of withdrawing FTB-A on joint income, holding demographics constant. The table reports the data means of family tax benefits for a subsample of families selected on the further criterion

10 This allows us to control for variation in the gross wage across employment status. Both groups are found to have close to the same predicted second wage within each quintile until towards the top percentiles. We can therefore conclude that the high degree of heterogeneity at a given primary income cannot be driven by the second wage alone. Apps and Rees (2017) show that the heterogeneity can, however, be explained by variation in the price of child care as a tax on the second wage. 
that there are two, and only two, dependant children aged five to 18 years present. The additional burden for the second earner in each quintile is given by the gap between the FTB-A payments for $\mathrm{H} 1$ and $\mathrm{H} 2$. Those who lose the most are $\mathrm{H} 2$ households in the lower half of the distributionin other words, low- and average-wage working mothers. This outcome is concealed by studies that report results for the distribution of family tax benefits by household income, a practice that reflects the assumption that the non-participating partner in the $\mathrm{H} 1$ household does not contribute to family welfare.

The child care benefit (CCB) and child care rebate (CCR) need to be included in the calculation of the tax on the second income. For the demographic group represented in Table 3.5b, the data means for both are relatively small, at $\$ 51$ and $\$ 49$ for the $\mathrm{H} 1$ household and $\$ 115$ and $\$ 423$ for the $\mathrm{H} 2$ household, for the CCB and CCR respectively. As we would expect, the CCB begins at a maximum in quintile 1 and falls to zero in quintile 5, while CCR has the reverse profile.

In contrast, the data means for CCB and CCR for 'in-work' families with a child aged zero to four are much larger for both household groups, at $\$ 1,166$ and $\$ 1,177$ per annum for the $\mathrm{H} 1$ household and $\$ 1,611$ and $\$ 2,852$ for the $\mathrm{H} 2$ household, respectively. The gap between data means across quintiles indicate that, on average, the higher claims for CCB and CCR by the $\mathrm{H} 2$ household contribute relatively little to reducing the far higher income tax burden on the second earner in two-earner households. Again, there is wide variation in the distribution of both CCB and CCR within each quintile. Given that the price of child care can exceed $\$ 100$ per day this is not surprising. It is now widely recognised that the earnings of many partnered mothers, net of taxes and child care costs, can be negative. Thus, unless the family has access to informal care, such as a grandparent, working full time using formal care may not be financially viable. These conditions can be expected to contribute significantly to the high degree of heterogeneity in second-earner labour supply at a given primary income and second wage.

The preceding analysis highlights not only the loss of tax revenue due to labour supply outcomes under the current system of quasi-joint family taxation, but when viewed in the context of the income tax reforms outlined in Part 2, successive governments can be seen to have drawn heavily on the earnings of low- to average-wage working mothers as second earners for funding tax cuts across the top percentiles of income. 


\section{Participation rates and life-cycle labour supply}

While female participation rates have risen since the 1970s, Australian rates have been lower than those of many comparable Organisation for Economic Co-operation and Development (OECD) countries. As reported in Treasury (2015b):

while the participation rate of women between the ages of 15 to 64 in Australia has increased from 65.3 percent in 2000 to 70.5 per cent in 2013, Australia is ranked 13th of the 34 OECD countries for female participation (p. 44).

However, of greater concern is the far wider gap in labour supply. While the vast majority of males work full time, the majority of females in employment choose part-time work, a decision that can allow a larger share of FTB-A payments to be retained and high child care costs to be reduced. In the sample used to construct Table $3.5 \mathrm{a}$, the participation rate of the second partner is 71 per cent and, on the basis of gender, 73.6 per cent. The gap in hours, however, is close to 50 per cent in both cases, and tends to persist in later years of the life cycle.

To assess more broadly the effects of high tax rates on partnered mothers as second earners, together with the high cost of child care in a largely privatised system, we need to organise the data according to a life cycle defined, not in terms of the age of 'head of household' as in the economics literature, but across phases that take account of the age and presence of dependant children. Using data for the sample of 'in-work' couples selected from the HES 2009-10 described previously, Table 3.6 presents average male and female hours of market work for four life-cycle phases as listed in the table. In the pre-child phase, which is represented by a relatively small subset of households in the sample, average female hours are over 85 per cent of average male hours. In the preschool phase, female hours fall to around a third of male hours, and then rise to 55 per cent in phase 3 . In phase 4 , when there are no longer dependant children present, female hours rise to just below 60 per cent of male hours, an outcome that is typically interpreted in the literature as evidence of persistence throughout the life cycle of decisions made in the earlier child rearing phases due to loss of human capital (see, for example, Shaw 1994). 
Table 3.6: Life cycle labour supply by gender

\begin{tabular}{|l|c|c|}
\hline Phase & Male hours & Female hours \\
\hline 1: Pre-children & 2,213 & 1,882 \\
\hline 2: At least one child of preschool age & 2,127 & 764 \\
\hline 3: Dependant child above preschool age & 2,103 & 1,158 \\
\hline 4: Pre-retirement-no dependant children & 1,803 & 1,078 \\
\hline
\end{tabular}

Source: Author's calculations based on ABS HES data for 2009-10.

In an analysis of time use data from the ABS Time Use Survey 2006 (Apps and Rees 2010), we find that while the market hours of partnered mothers are at their lowest average in phase 2, their average total working hours are at a maximum when calculated as the sum of market hours and time allocated to child care and domestic work (see also the analysis of time allocated to child care based on the same survey by Huong Dinh and Maria Racionero in Chapter 7, this volume). Male total hours of work, while below female total hours, are also at a maximum in phase 2 . Thus each partner's 'pure leisure' is lower in phase 2 than at any other time in the family's life cycle. The data also show that market consumption expenditure is at its lowest point in phase 2. It is a phase in which the couple feels itself very short of both time and money. Economic models of the life cycle based on the assumption of a 'perfect' capital market, in which couples can borrow against future income at an interest rate as low as that paid on savings accounts, predict that they would do that to 'smooth' their consumption over time and ease the tightness of the constraints they face. In Apps and Rees (2010) the fact that they do not do so is taken as evidence that they face an 'imperfect' capital market in which borrowing, if it can be done at all, has to be at a rate well above the rate on savings, for example the credit card rate. Household expenditure data indicate that the problem is more acute when the ability of the family to offer collateral is lower.

These capital market conditions call for a program of public investment in child care to reduce the negative effects on female labour supply and to provide all children with equal access to early learning opportunities. A privatised system supported by price/cost subsidies is not a solution in this type of imperfect capital market, and in a child care market in which prices are driven by rising property values and profit seeking. Under the current policy approach, many parents will continue to have insufficient collateral to borrow at an affordable interest rate during the preschool years. 


\section{Household saving effects}

When we turn to the data on household incomes and earnings we find, as we would expect, that median household income tracks median female earnings over the four life-cycle phases. We also find that median household saving, calculated as the difference between disposable income and consumption expenditure, tracks female earnings, as indicated in Table 3.7. The profiles provide strong evidence that tax policies with a negative effect on female labour supply have a flow-on negative effect on household saving.

Table 3.7: Life-cycle median household income, earnings and saving

\begin{tabular}{|l|c|c|c|}
\hline Phase & $\begin{array}{c}\text { Household } \\
\text { income }\end{array}$ & $\begin{array}{c}\text { Female } \\
\text { earnings }\end{array}$ & Saving \\
\hline 1: Pre-children & $\$ 116,141$ & $\$ 47,502$ & $\$ 19,760$ \\
\hline 2: At least one child of preschool age & $\$ 83,824$ & $\$ 6,240$ & $\$ 5,824$ \\
\hline 3: Dependant child above preschool age & $\$ 110,244$ & $\$ 30,212$ & $\$ 9,776$ \\
\hline 4: Pre-retirement-no dependant children & $\$ 94,744$ & $\$ 26,208$ & $\$ 14,040$ \\
\hline
\end{tabular}

Source: Author's calculations based on ABS HES data for 2009-10.

The strong positive relationship between household saving and second earnings holds across the entire distribution of primary income. In Table 3.8, households are ranked by primary income quintiles and the subsample within each quintile is split into subsamples labelled $\mathrm{H} 1$ and $\mathrm{H} 2$ according to median second earnings. The table reports quintile data means of second earnings and regression estimates of household saving that control for the number and age of children.

Table 3.8: Second earnings and saving by primary income

\begin{tabular}{|l|l|c|c|c|c|c|}
\hline \multicolumn{2}{|l|}{ Primary income quintiles \$pa } & 34,265 & 54,701 & 71,982 & 96,648 & 201,855 \\
\hline \multirow{2}{*}{ H1: } & 2nd earnings \$pa & 330 & 9,745 & 9,494 & 16,794 & 12,835 \\
\cline { 2 - 7 } & Saving \$pa & $-8,227$ & 331 & 4,095 & 14,268 & 54,642 \\
\hline \multirow{2}{*}{ H2: } & 2nd earnings \$pa & 24,425 & 37,410 & 43,001 & 60,451 & 67,281 \\
\cline { 2 - 7 } & Saving \$pa & 297 & 9,075 & 16,167 & 30,634 & 76,973 \\
\hline
\end{tabular}

Source: Author's calculations based on ABS HES data for 2009-10.

The results reflect a second-earner saving rate that is significantly higher than that of the primary earner. The aggregate level of saving across quintiles 2 to 4 by $\mathrm{H} 2$ households exceeds that of the top quintile of $\mathrm{H} 1$ 
households. Reforms that raise effective tax rates on partnered mothers as second earners in order to fund lower top tax rates or a revenue shortfall from lower taxes on saving or capital income can therefore be expected to have the perverse effect of reducing the overall level of saving.

The analysis serves to highlight the importance of recognising the role of women in the economy, and the irrelevance of Treasury's CGE modelling approach that evaluates the economic cost of direct and indirect taxes on the basis of a model of the household as a single person with a single labour supply elasticity and marginal excess tax burden, and a single saving rate in a perfectly competitive capital market.

\section{Demographic change and retirement incomes policy}

\section{Demographic change}

Successive Intergenerational Reports (IGRs) have focused almost exclusively on the potential for budget deficits resulting from a rising aged dependency ratio (ADR), the ratio of people aged 65 and over to those aged 15-64. Dramatising the projected rise in the ADR in the coming decades is, however, misleading when a decline in the TFR is a major cause of population ageing. The focus of attention needs to be directed towards the total dependency ratio (TDR), the ratio of the total non-working to working-age population, and this includes the child dependency ratio (CDR), the ratio of those aged 0-14 to those aged 15-64. With the fall in TFR from 3.5 in the early 1960s to 1.8 today, the CDR is falling while the ADR is rising, due both to the fall in the TFR and increasing longevity. The historical graph of the overall TDR profile for Australia is U-shaped, with the rate in the early 1960s close to IGR projections for the middle of this century.

To assess the true effects of demographic change, the CDR and ADR need to be weighted by cost. It is straightforward to calculate that the resources required by a child are far greater than those required, on average, by a retiree. Every child requires at least a decade of parental and public investment in her/his education. Most importantly, every preschool child requires full-time care. Time use data reveal that a child is extremely costly in terms of parental time. The decline in the CDR 
since the 1960s therefore creates the potential for a significant 'social dividend'. Demographic change presents a resource reallocation problem, not a saving problem.

The key challenge is to put in place a set of reforms that allow the reallocation of parental time, primarily female labour time, from the home to the market. Under the required reforms, we would expect to see an expansion of the tax base that would provide additional revenue for productivity improving investments in child care, education, health care and the economy's infrastructure.

The preceding analysis of life-cycle profiles of female labour supply and the high degree of heterogeneity after the first child show the limited extent to which this outcome has been achieved. With the rise in female participation and the growth in the tax base since the 1960s, one of the major and most obvious policy mistakes has been the failure to invest incrementally in a publicly owned, early learning child care system. Instead, from 2004 to 2008, we saw much of the growth in tax revenues directed towards reducing the progressivity of the income tax and, over the last two decades, the gradual introduction of a system of quasi-joint taxation of families that shifts the tax burden from top incomes towards partnered mothers as second earners. This direction of reform, together with costly and limited access to child care, offers an explanation for Australia's poor performance in terms of female participation rates relative to comparable OECD countries and the persistent gender pay gap.

\section{Superannuation vs the age pension}

We now turn to retirement incomes policy (and see also Siobhan Austen and Rhonda Sharp in Chapter 10). Successive governments have focused on saving as the solution to the challenges presented by demographic change, and to this end have supported the expansion of Australia's tax-advantaged defined contribution superannuation system. The aim of the system is said to be that of replacing the public, pay-as-you-go (PAYG), non-contributory age pension with a mandatory fully funded private system over time. It is argued that because of the rising ADR, the age pension will become unaffordable. This argument is fundamentally flawed at several levels. 
First, the argument fails to recognise that switching from a PAYG to a funded pension system cannot, per se, lead to an efficiency gain, as demonstrated by the famous Samuelson (1958) theorem for overlapping generation economies. ${ }^{11}$ There is now a large body of research that draws on the Samuelson model to show that the switch to a fully funded scheme cannot be a solution to the problems raised by declining fertility and increasing ADRs (see, for example, Breyer 1989; Orszag and Stiglitz 1999). If it were true that the ratio of the dependant population to working-age population, weighted by cost, was necessarily rising, outcomes under a PAYG pension system and a fully funded system in a perfect capital market are identical. As shown by the Samuelson model, a negative interest rate in the latter case will achieve exactly the same outcome as the optimal changes to taxes and pension payments in the PAYG system. Moreover, a shift from PAYG to fully funding can make some members of the present working generation pay twice- they are forced to save for their own retirement while continuing to pay taxes that finance the pensions of the currently retired. Under Australia's tax-advantaged defined contribution superannuation system, women on relatively low pay face a high probability of this outcome. Their taxes support current pension payments while their relatively low super savings on retirement may exclude them from an approximately equivalent payment under the age pension.

Second, and more fundamentally, Australia's defined contribution superannuation system is not a retirement incomes policy. According to modern public economic theory, the key objective of a retirement incomes policy is the provision of insurance against longevity and aggregate (or social) risk in response to the inherent market failures and high transaction costs associated with the private provision of contracts to cover these risks. To deal with the issue of risk, we require a defined benefit system.

Australia's defined contribution superannuation system, with employer contributions and entity earnings taxed at 15 per cent, fails to provide insurance against longevity and aggregate risk. It is essentially a taxadvantaged saving scheme that provides the greatest gains for those with the most income to save. The benefits of the tax concessions go predominantly to primary earners, as shown in Figure 3.3, which is based on the HES 2009-10 sample of 'in-work' couples. The figure plots the distribution of primary- and second-earner superannuation balances by primary income.

11 Note that the theorem assumes a defined benefit system; that is, a true retirement income system. 


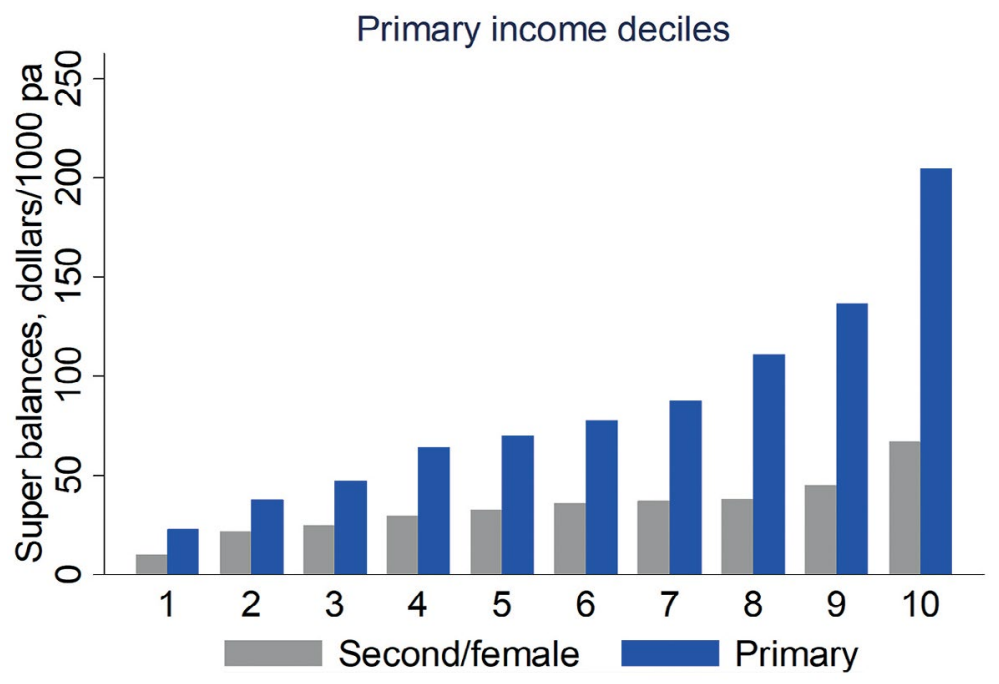

Figure 3.3: Primary/second-earner superannuation balances by primary income

Source: Author's calculations based on ABS HES data for 2009-10.

Given the gender gap in both pay and labour supply, women as a group cannot gain from tax-advantaged superannuation. The overall impact of the system is to widen the net-of-tax gender pay gap due to the preferential tax treatment of those on higher pay. It is therefore something of a puzzle that the Senate Economics Reference Committee Report, Economic Security for Women in Retirement (Commonwealth of Australia 2016), supports an increase in the Superannuation Guarantee to 12 per cent, and recommends that the planned gradual increase be implemented earlier than under the current timetable.

In addition to the limitations of the system with respect to equity, a significant loss is associated with privatisation due to high administrative costs (fees, commissions, advertising, excessive executive pay, etc.). It is recognised in the literature that administrative costs for public sector schemes are far lower. There is a clear trade-off: it is administratively less expensive to provide a uniform retirement program for all individuals than to have a large number of competing programs available, among which individuals can choose. It is generally accepted that the optimal policy is a universal public pension. The implementation of a universal pension is, however, likely to be strongly opposed by those who fail to understand the concept of economic cost, as discussed in the context of universal family payments in the preceding section. 
As the limitations of the superannuation system become increasingly recognised, a frequent response is to shift the argument used to support much of its preferential tax treatment. Recent Budget estimates of the tax expenditure on superannuation concessions have exceeded $\$ 30$ billion based on the comprehensive income tax benchmark. This figure is rejected by those who argue that the calculation should take account of opportunities for tax avoidance, for example through the use of trusts and negative gearing, to give a more reliable lower estimate.

It has also been argued that much of the tax expenditure can be justified in terms of reducing the double taxation of saving. Under a comprehensive income tax saving is said to be taxed twice and that the ideal tax system would exempt capital income (see, for example, Commonwealth of Australia 2008). The proposition that the optimal tax rate on capital is zero contradicts the central tenet of modern tax theory, that the optimal tax rate on a given source of income, whether labour or capital, can only be determined on the basis of empirical evidence on distributional outcomes and behavioural effects because we are in a 'second-best' setting. Even if capital were highly mobile, which is very much open to question in a number of important contexts, this does not imply an optimal rate of zero.

If we attempt to move towards a low capital income tax regime, for example, by increasing mandatory contributions to superannuation or cutting the company income tax rate, taxes elsewhere will have to rise. If the ongoing policy agenda persists, we can expect further shifts in the burden of taxation towards three groups - the 'middle', working married mothers and the next generation-with negative effects on the tax base, productivity and growth.

\section{Conclusion}

Reforms to the Australian tax-transfer system in recent decades have been directed towards shifting the tax burden from the top percentiles of the income distribution towards those on or below average earnings, in an economic environment of growing inequality in wages, incomes and wealth. This is clearly demonstrated through the survey data presented in this chapter. In addition, the simultaneous introduction of joint incometested family payments has shifted the tax burden towards working partnered mothers, providing a further source of revenue for cutting top 
tax rates. Important consequences include a widening of the net-of-tax gender pay gap and a failure to promote the kinds of resource reallocations required for achieving fiscal sustainability in the face of demographic change.

Many of the policy views in recent Treasury reports suggest that there is little to no improvement in sight. All too frequently recommended reforms, such as lower top income tax rates, a tax-mix change through the expansion of the goods and services tax (GST) and lower capital income taxes, draw on economic models that are inconsistent with the evidence on behavioural effects, and which proceed as if we lived in a world in which women do not exist. Better economic models are readily available that would support a change in direction in the key policy areas considered in this paper: the restoration of a truly progressive, individual-based income tax system with effective constraints on evasion and avoidance; investment in the development of a high-quality, early learning public child care system; and recognition of the superiority of a publicly funded age pension system over a privatised and inequitably tax-advantaged defined contribution superannuation system. In short, this chapter advocates for the reversal of the policies introduced over the past three decades, often under cover of measures that disguise their real effects and supported by spurious and misleading arguments, the cumulative effects of which have been to construct an Australian tax system that is both less efficient and less fair, not least in the way that it treats working women.

\section{References}

ABS (Australian Bureau of Statistics). 2016. Average Weekly Earnings, Australia, Cat. no. 6302.0.

Andrienko, Yuri, Patricia Apps and Ray Rees. 2016. 'Optimal Taxation and Top Incomes'. International Tax and Public Finance 23(6): 981-1003. doi.org/10.1007/s10797-015-9391-y

Apps, Patricia. 1982. 'Institutional Inequality and Tax Incidence'. Journal of Public Economics 18(2): 217-242. doi.org/10.1016/00472727(82)90004-4 
Apps, Patricia. 2010. 'Why the Henry Review Fails on Family Tax Reform'. In Chris Evans, Richard Krever and Peter Mellor (eds), Australia's Future Tax System: The Prospects after Henry, pp. 103-127. Australia: Thomson Reuter Australia Ltd.

Apps, Patricia, Ngo Long and Ray Rees. 2014. 'Optimal Piecewise Linear Income Taxation'. Journal of Public Economic Theory 16(4): 523-545. doi.org/10.1111/jpet.12070

Apps, Patricia and Ray Rees. 1988. 'Taxation and the Household'. Journal of Public Economics 35(3): 355-369. doi.org/10.1016/00472727(88)90037-0

Apps, Patricia and Ray Rees. 2009. Public Economics and the Household. Cambridge: Cambridge University Press. doi.org/10.1017/ CBO9780511626548

Apps, Patricia and Ray Rees. 2010. 'Family Labour Supply, Taxation and Saving in an Imperfect Capital Market'. Review of Economics of the Household 8: 297-323. doi.org/10.1007/s11150-010-9094-1

Apps, Patricia and Ray Rees. 2013. 'Raise Top Tax Rates, Not the GST'. Australian Tax Forum 28(3): 679-693. doi.org/10.2139/ssrn.2291299

Apps, Patricia and Ray Rees. 2017. 'Optimal Family Taxation and Income Inequality'. Sydney Law School Research Paper No. 17/09. dx.doi. org/10.2139/ssrn.2910797

Atkinson, Antony. 2015. Inequality: What can be done? Harvard University Press. doi.org/10.4159/9780674287013

Boskin, Michael and Eytan Sheshinski. 1983. 'Optimal Tax Treatment of the Family: Married Couples'. Journal of Public Economics 20(3): 281-297. doi.org/10.1016/0047-2727(83)90027-0

Breyer, Friedrich. 1989. 'On the Intergenerational Pareto Efficiency of Pay-As-You-Go Pension Systems'. Journal of Institutional and Theoretical Economics 145(4): 643-658.

Cao, Liangyue, Amanda Hosking, Michael Kouparitsas, Damian Mullaly, Xavier Rimmer, Qun Shi, Wallace Stark and Sebastian Wende. 2015. 'Understanding the Economy-Wide Efficiency and Incidence of Major Australian Taxes'. Treasury Working Paper, WP 2015-01, Australian Government. 
Commonwealth of Australia. 2008. Australia's Future Tax System: Retirement Income Consultation Paper. Canberra: Commonwealth of Australia.

Commonwealth of Australia. 2016. Economic Security for Women in Retirement. Report of the Senate Economics Reference Committee. Canberra: Commonwealth of Australia.

Henry, Ken et al. 2009. Review of Australia's Future Tax System: Report to the Treasurer. Australia's Future Tax System Review Panel (the 'Henry Review'). Available at: taxreview.treasury.gov.au

Institute for Fiscal Studies and James Mirrlees. 2011. Tax by Design: The Mirrlees Review. Oxford: Oxford University Press.

KPMG. 2010. CGE Analysis of the Current Australian Tax System. Canberra: Department of Treasury.

KPMG. 2011. 'Economic Analysis of the Impact of Using GST to Reform Taxes'. Report prepared for CPA Australia.

Moffitt, Robert and Mark Wilhelm. 2000. 'Taxation and the Labor Supply Decisions of the Affluent'. In Joel Slemrod (ed.), Does Atlas shrug? The Economic Consequences of Taxing the Rich, pp. 193-234. New York: Russell Sage Foundation; Cambridge and London: Harvard University Press.

Orszag, Peter and James Stiglitz. 1999. 'Rethinking Pensions Reform: Ten Myths about Social Security Systems'. In Robert Holzmann and Joseph Stiglitz (eds), New Ideas about Old Age Security, pp. 17-56. Washington: World Bank.

Peter, Klara Sabirianova, Steve Buttrick and Denvil Duncan. 2010. 'Global reform of personal income taxation, 1981-2005: Evidence from 189 countries’. National Tax Journal 63(3): 447-478. doi.org/10.17310/ntj.2010.3.03

Piketty, Thomas and Emmanuel Saez. 2003. 'Income Inequality in the United States, 1913-1998'. Quarterly Journal of Economics 118(1): 1-39. doi.org/10.1162/00335530360535135 
Piketty, Thomas, Emmanuel Saez and Stefanie Stantcheva. 2014. 'Optimal Taxation of Top Labor Incomes: A Tale of Three Elasticities'. American Economic Journal: Economic Policy 6(1): 230-271. doi.org/10.1257/ pol.6.1.230

Samuelson, Paul. 1958. 'An Exact Consumption-Loan Model of Interest with or without the Social Contrivance of Money'. Journal of Political Economy 66(6): 467-482. doi.org/10.1086/258100

Shaw, Kathryn. 1994. 'The Persistence of Female Labor Supply: Empirical Evidence and Implications'. Journal of Human Resources 29(2): 348378. doi.org/10.2307/146102

Treasury. 2015a. Intergenerational Report: Australia in 2055. Canberra: Commonwealth of Australia. Available at: treasury.gov.au/ publication/2015-intergenerational-report/

Treasury. 2015b. Re:Think Tax Discussion Paper. Australian Government. Available at: bettertax.gov.au/files/2015/03/TWP_combined-online.pdf

WGEA (Workplace Gender Equality Agency). 2016. Gender Pay Gap Statistics, March, Australian Government. Available at: www.wgea. gov.au 
This text is taken from Tax, Social Policy and Gender: Rethinking equality and efficiency, edited by Miranda Stewart, published 2017 by ANU Press, The Australian National University, Canberra, Australia.

dx.doi.org/10.22459/TSPG.11.2017.03 